Agro-Science Journal of Tropical Agriculture, Food, Environment and Extension Volume 10 Number 2 Mav 2011 pp. $58-68$

ISSN1119-7455

\title{
GENERATION BY GENERATION CORRELATION AND PATH ANALYSIS FOR YIELD AND YIELD COMPONENTS IN ADVANCED GENERATIONS OF TOMATO (SOLANUM SPECIES) HYBRIDS.
}

\author{
Atugwu A. I. and Uguru M.I. \\ ${ }^{1}$ Natural Science Unit, School of General Studies University of Nigeria, Nsukka. Nigeria. \\ ${ }^{2}$ Department of Crop Science, University of Nigeria, Nsukka, Nigeria.
}

\begin{abstract}
Six advanced generations $\left(F_{7}, F_{12}\right)$ of tomato hybrids were evaluated in the Department of Crop Science Research Farm, University of Nigeria, Nsukka from 2004 to 2008 to estimate the magnitude of character association of yield and yield related attributes in each filial generation. Traits under focus were days to flowering, number of flowers, number of fruits, number of trusses and number branches per plant and fresh fruit yield per plant. Positive and highly significant correlations were observed between fresh fruit yield and number of flowers, number of trusses and branches per plant in the six generations studied. Fresh fruit yield showed negative association with days to flowering in the $F_{8}, F_{10}$ and $F_{12}$ generations. Path analysis revealed highest positive direct effect of number of flowers per plant on fruit yield. The high negative indirect effect exhibited by number of flowers per plant at the $F_{7}, F_{10}$ and $F_{12}$ generations were counteracted by the high positive indirect effect via number of flowers per truss at $F_{7}$, number of trusses at $F_{10}$ and number of fruits at $F_{12}$. Number of flowers per plant exhibited highest positive direct effect consistently in three out of the six generations studied. Selection based on number of flowers per plant should therefore, be considered for high fruit yield in tomato.
\end{abstract}

Key words: Tomato, correlation, path coefficient Analysis, Solanum species.

\section{INTRODUCTION}

The knowledge of inter-relationships existing among various characters is necessary when selection for simultaneous improvement of traits is the target of the plant breeder. If two desirable characters are associated, selection for one character will automatically be good enough to make meaningful improvement of the other. Grafius (1959) reported that there may not be genes for yield as such, as the loci for yield operate only through its components. So correlation analysis provides the information on nature and magnitude of the association of different components that are responsible for yield. It is therefore important for plant breeders to ascertain the level of correlation between the characters and fruit yield. Understanding such relationships will enable plant breeders to capture the important traits during selection (Sarawgi, et al., 1997). Due to their mutual association, the development of a dependent variable and their indirect effect exerted through other characters arises inevitably as an integral part of growth and development. Under such complex situation, the total correlation would be insufficient to explain the association for effective manipulation of the characters (Dewey and lu, 1959). Path analysis provides the means of partitioning the correlation into direct and indirect effects and measures the relative importance of the factors involved. The combined use of correlation and path analysis would provide a better understanding of the association of different characters with yield (Mahmudul, et al., 2005). Correlation and path analysis have been used by Rani, et al. (2008) and Hidayatullah, et al. (2008) to estimate character association in fruit yield and other yield component characters in early generations of tomato hybrids. Literature on correlation and path analysis on yield and yield components in advanced generations of tomato hybrids is not available. Yet this information would assist in simultaneous selection of yield determining traits. This work was therefore initiated to investigate the contributions of some of the yield traits in advanced generations of tomato hybrids.

DOI: http://dx.doi.org/10.4314/as.v10i2.8 


\section{MATERIALS AND METHODS}

The materials for the study comprised four parents namely: Roma, Wild, Local, Tropica and six advanced generations $\left(F_{7}\right.$ to $\left.F_{12}\right)$ of interspecific hybrids obtained from the crosses between some commercially cultivated tomato varieties (S.lycopersicum) and the wild relative (S. pimpinellifolium). Six plantings were carried out in the Department of Crop Science Research Farm, University of Nigeria, Nsukka from 2004 to 2008. The seedlings were raised in shallow drills in nursery boxes under shade. Watering was done manually using watering can. The seedlings were transplanted in single row plots at an inter-row spacing of $45 \mathrm{~cm}$ on ridges spaced $1 \mathrm{~m}$ apart. Each ridge measured $1 \mathrm{~m}$ x $27 \mathrm{~m}$. Well cured poultry manure was applied at the rate of 1.8t/ha. The seedlings were transplanted at four weeks after planting (WAP).Weeding was done manually using a weeding hoe. Data were collected on days to flowering, fresh fruit yield $(\mathrm{g})$, number of flowers, fruits, trusses and branches per plant and number of flowers and fruits per truss

\section{Statistical Analyses.}

The Correlation values were obtained using SPSS for window version 16 .0. Path coefficient analysis was carried out by partitioning the correlation coefficient into direct and indirect effects to find out the contributions of the yield components to fresh fruit yield per plant at every generation using the Analysis for Moment Structure (AMOS) software programme.

\section{RESULTS}

The results of the correlation coefficients for the different generations are presented in Tables 1 to 6 .

\section{$\mathbf{F}_{7}$ generation:}

The correlation values between fresh fruit yield and the yield components at the $\mathrm{F}_{7}$ generation are presented in Table1. Fresh fruit yield showed positive and highly significant correlations with trusses/plant $(0.173 * *)$, flowers/truss $(0.250 * *)$ and fruits/truss $(0.203 * *)$. The associations of fresh fruit yield and days to flowering, number of flowers per plant, number of fruits per plant and number of branches per plant are positive but not significant. Days to flowering showed positive and significant association with number of flowers per truss and number of fruits per truss. Other traits showed positive and non significant relationship with days to flowering.

\section{$F_{8}$ generation:}

The correlation values at the $\mathrm{F}_{8}$ generation are presented in Table 2. Positive and highly significant correlation were observed between fresh fruit yield and number of flowers $(0.521)$ fruits $\left(0.496^{* *}\right)$, trusses $(0.527 * *)$ and branches $\left(0.295^{* *}\right)$ per plant. Fresh fruit yield had significant negative association with days to flowering. The relationships between days to flowering and all other traits were negative except for number of flowers per truss and number of fruits per truss. The other traits showed positive and significant association with one another as in generation 7 .

Table.1: Correlation coefficients among different characters in $F_{7}$ generation of tomato genotype

\begin{tabular}{lllllllll}
\hline 7 & $\mathrm{D} / \mathrm{FL}$ & $\mathrm{Fl} / \mathrm{P}$ & $\mathrm{Fr} / \mathrm{P}$ & $\mathrm{Tr} / \mathrm{P}$ & $\mathrm{Br} / \mathrm{P}$ & $\mathrm{FL} / \mathrm{T}$ & $\mathrm{Fr} / \mathrm{T}$ & Frfrtwt \\
\hline $\mathrm{D} / \mathrm{FL}$ & 1 & & & & & & & \\
$\mathrm{Fl} / \mathrm{P}$ & .097 & 1 & & & & & & \\
$\mathrm{Fr} / \mathrm{P}$ & .110 & $.961^{* *}$ & 1 & & & & & \\
$\mathrm{Tr} / \mathrm{P}$ & .090 & $.824^{* *}$ & $.827^{* *}$ & 1 & & & & \\
$\mathrm{Br} / \mathrm{P}$ & .104 & $.847^{* *}$ & $.859^{* *}$ & $.895^{* *}$ & 1 & & & \\
$\mathrm{FL} / \mathrm{T}$ & $.207^{* *}$ & $.811^{* *}$ & $.832^{* *}$ & $.777^{* *}$ & $.823^{* *}$ & 1 & & \\
$\mathrm{Fr} / \mathrm{T}$ & $.167^{*}$ & $.834^{* *}$ & $.860^{* *}$ & $.848^{* *}$ & $.866^{* *}$ & $.895^{* *}$ & 1 & \\
Frfrwt & .094 & .110 & .110 & $.173^{* *}$ & .122 & $.250^{* *}$ & .203 & 1 \\
\hline
\end{tabular}

$\mathrm{D} / \mathrm{fl}=$ days to flowering, $\mathrm{Fl} / \mathrm{p}=$ number of flowers/plant, $\mathrm{Fr} / \mathrm{p}=$ number of fruits/plant, $\mathrm{Tr} / \mathrm{p}=$ number of trusses/plant, $\mathrm{Br} / \mathrm{p}=$ number of branches/plant, $\mathrm{Fl} / \mathrm{t}=$ number of flowers/truss and $\mathrm{Fr} / \mathrm{t}=$ number of fruits/truss FrFrwt=Fruit weight

Table.2: Correlation coefficients among different characters in $F_{8}$ generation of tomato genotypes

\begin{tabular}{lllllllll}
\hline 8 & $\mathrm{D} / \mathrm{FL}$ & $\mathrm{Fl} / \mathrm{P}$ & $\mathrm{Fr} / \mathrm{P}$ & $\mathrm{Tr} / \mathrm{P}$ & $\mathrm{Br} / \mathrm{P}$ & $\mathrm{FL} / \mathrm{T}$ & $\mathrm{Fr} / \mathrm{T}$ & Frfrtwt \\
\hline $\mathrm{D} / \mathrm{FL}$ & 1 & & & & & & & \\
$\mathrm{Fl} / \mathrm{P}$ & -.096 & 1 & & & & & & \\
$\mathrm{Fr} / \mathrm{P}$ & -.058 & $.982^{* *}$ & 1 & & & & & \\
$\mathrm{Tr} / \mathrm{P}$ & -.058 & $.911^{* *}$ & $.893^{* *}$ & 1 & & & & \\
$\mathrm{Br} / \mathrm{P}$ & -.017 & $.589^{* *}$ & $.594^{* *}$ & $.568^{* *}$ & 1 & & & \\
$\mathrm{FL} / \mathrm{T}$ & $.109^{*}$ & $.717^{* *}$ & $.735^{* *}$ & $.667^{* *}$ & $.582^{* *}$ & 1 & & \\
$\mathrm{Fr} / \mathrm{T}$ & .073 & $.725^{* *}$ & $.753^{* *}$ & $.659^{* *}$ & $.603^{* *}$ & $.931^{* *}$ & 1 & \\
Frfrwt & $-.263^{* *}$ & $.512^{* *}$ & $.496^{* *}$ & $.527^{* *}$ & $.295^{*}$ & $.264^{* *}$ & .263 & 1 \\
& & & & & & & & \\
\hline
\end{tabular}

$\mathrm{D} / \mathrm{fl}=$ days to flowering, $\mathrm{Fl} / \mathrm{p}=$ number of flowers/plant, $\mathrm{Fr} / \mathrm{p}=$ number of fruits/plant, $\mathrm{Tr} / \mathrm{p}=$ number of trusses/plant, $\mathrm{Br} / \mathrm{p}=$ number of branches/plant, $\mathrm{Fl} / \mathrm{t}=$ number of flowers/truss and $\mathrm{Fr} / \mathrm{t}=$ number of fruits/truss FrFrwt=Fruit weight.

\section{F9 generation:}

The correlation values at $\mathrm{F}_{9}$ generation revealed positive and significant association, between fresh fruit yield and number of flowers, fruits, trusses and branches per plant (Table 3). High and significant correlations were observed among number of flowers, fruits, trusses, branches per plant; flowers and fruits per truss. 
Table.3: Correlation coefficients among different characters in $\mathrm{F}_{\mathbf{9}}$ generation of tomato Genotypes

\begin{tabular}{|c|c|c|c|c|c|c|c|c|}
\hline 9 & $\mathrm{D} / \mathrm{FL}$ & $\mathrm{Fl} / \mathrm{P}$ & $\mathrm{Fr} / \mathrm{P}$ & $\operatorname{Tr} / \mathrm{P}$ & $\mathrm{Br} / \mathrm{P}$ & $\mathrm{FL} / \mathrm{T}$ & $\mathrm{Fr} / \mathrm{T}$ & Frfrtwt \\
\hline$\overline{\mathrm{D} / \mathrm{FL}}$ & 1 & & & & & & & \\
\hline $\mathrm{Fl} / \mathrm{P}$ & -.083 & 1 & & & & & & \\
\hline $\mathrm{Fr} / \mathrm{P}$ & -.092 & $.991^{* *}$ & 1 & & & & & \\
\hline $\mathrm{Tr} / \mathrm{P}$ & -.091 & $.832^{* *}$ & $.836^{* *}$ & 1 & & & & \\
\hline $\mathrm{Br} / \mathrm{P}$ & .122 & $.755^{* *}$ & $.755^{* *}$ & $.699^{* *}$ & 1 & & & \\
\hline $\mathrm{FL} / \mathrm{T}$ & -.144 & $.800^{* *}$ & $.792^{* *}$ & $.606^{* *}$ & $.570^{* *}$ & 1 & & \\
\hline $\mathrm{Fr} / \mathrm{T}$ & $.180^{*}$ & $.734^{* *}$ & $.752^{* * *}$ & $.618^{* *}$ & $.578^{* *}$ & $.888^{* *}$ & 1 & \\
\hline Frfrtwt & .009 & $.568^{* *}$ & $.567^{* *}$ & $.515^{* *}$ & $.399^{* *}$ & $.288^{* *}$ & $.305^{* *}$ & 1 \\
\hline
\end{tabular}

$\mathrm{D} / \mathrm{fl}=$ days to flowering,Fl/p=number of flowers/plant, $\mathrm{Fr} / \mathrm{p}=$ number of fruits/plant,Tr/p=number of trusses/plant, Br/p=number of branches/plant, $\mathrm{Fl} / \mathrm{t}=$ number of flowers/truss and $\mathrm{Fr} / \mathrm{t}=$ number of fruits/truss FrFrwt=Fruit weight.

Table.4: Correlation coefficients among different characters in $\mathbf{F}_{10}$ generation of tomato genotypes.

\begin{tabular}{|c|c|c|c|c|c|c|c|c|}
\hline $\mathrm{D} / \mathrm{FL}$ & 1 & & & & & & & \\
\hline $\mathrm{Fl} / \mathrm{P}$ & $-.141^{* *}$ & 1 & & & & & & \\
\hline $\mathrm{Fr} / \mathrm{P}$ & $-.155^{* *}$ & $.959^{\text {** }}$ & 1 & & & & & \\
\hline $\mathrm{Tr} / \mathrm{P}$ & $-.144^{* *}$ & $.923^{\text {** }}$ & $.874^{* *}$ & 1 & & & & \\
\hline $\mathrm{Br} / \mathrm{P}$ & -.028 & $.854^{* *}$ & $.816^{* *}$ & $.845^{* *}$ & 1 & & & \\
\hline $\mathrm{FL} / \mathrm{T}$ & $-.207^{* *}$ & $.746^{\text {*** }}$ & $.722^{* *}$ & $.630^{* *}$ & $.565^{* *}$ & 1 & & \\
\hline $\mathrm{Fr} / \mathrm{T}$ & $-.294^{* *}$ & $.725^{\text {** }}$ & $.738^{* *}$ & $.639^{* * *}$ & $.582^{* *}$ & $.813^{* *}$ & 1 & \\
\hline Frfrtwt & -.025 & $.150^{\text {** }}$ & $.143^{\text {** }}$ & $.240^{* * *}$ & $.177^{* *}$ & .014 & .038 & 1 \\
\hline
\end{tabular}

$\mathrm{D} / \mathrm{fl}=$ days to flowering, $\mathrm{Fl} / \mathrm{p}=$ number of flowers/plant, $\mathrm{Fr} / \mathrm{p}=$ number of fruits/plant, $\mathrm{Tr} / \mathrm{p}=$ number of trusses/plant, $\mathrm{Br} / \mathrm{p}=$ number of branches/plant, $\mathrm{Fl} / \mathrm{t}=$ number of flowers/truss and $\mathrm{Fr} / \mathrm{t}=$ number of fruits/truss FrFrwt=Fruit weight.

Table.5: Correlation coefficients among different characters in $\mathbf{F}_{11}$ generation of tomato genotypes.

\begin{tabular}{|c|c|c|c|c|c|c|c|c|}
\hline 11 & D/FL & $\mathrm{Fl} / \mathrm{P}$ & $\mathrm{Fr} / \mathrm{P}$ & $\mathrm{Tr} / \mathrm{P}$ & $\mathrm{Br} / \mathrm{P}$ & $\mathrm{FL} / \mathrm{T}$ & $\mathrm{Fr} / \mathrm{T}$ & Frfrtwt \\
\hline$\overline{\mathrm{D} / \mathrm{FL}}$ & 1 & & & & & & & \\
\hline $\mathrm{Fl} / \mathrm{P}$ & .012 & 1 & & & & & & \\
\hline $\mathrm{Fr} / \mathrm{P}$ & .031 & $.964^{* *}$ & 1 & & & & & \\
\hline $\mathrm{Tr} / \mathrm{P}$ & .059 & $.717^{* * *}$ & $.696^{* *}$ & 1 & & & & \\
\hline $\mathrm{Br} / \mathrm{P}$ & $.110^{*}$ & $.570^{* * *}$ & $.529^{* * *}$ & $.646^{* *}$ & 1 & & & \\
\hline $\mathrm{FL} / \mathrm{T}$ & $.143^{* *}$ & $.720^{* * *}$ & $.716^{* *}$ & $.580^{* *}$ & $.431^{* *}$ & 1 & & \\
\hline $\mathrm{Fr} / \mathrm{T}$ & $.179^{* *}$ & $.679^{* * *}$ & $.687^{* *}$ & $.599^{* *}$ & $.404^{* *}$ & $.880^{* *}$ & 1 & \\
\hline Frfrtwt & $-.134^{* *}$ & .009 & -.041 & $.027^{* *}$ & -.13 & $-.261^{* *}$ & $-.245^{* *}$ & 1 \\
\hline
\end{tabular}

$\mathrm{D} / \mathrm{fl}=$ days to flowering,Fl/p=number of flowers/plant, $\mathrm{Fr} / \mathrm{p}=$ number of fruits/plant,Tr/p=number of trusses/plant, Br/p=number of branches/plant, $\mathrm{Fl} / \mathrm{t}=$ number of flowers/truss and $\mathrm{Fr} / \mathrm{t}=$ number of fruits/truss FrFrwt=Fruit weight.

\section{$F_{10}$ generation:}

The correlations among the traits at $\mathrm{F}_{10}$ generation are presented in Table 4. Fresh fruit yield exhibited positive and significant relationship with flowers per plant $\left(0.150^{* *}\right)$, fruits per plant $\left(0.143^{* *}\right)$, trusses per plant $(0.240 * *)$ and branches per plant $(0.177 * *)$. The yield traits showed positive and significant association with one another except for days to flowering that showed consistent negative correlation with all the yield traits.

\section{$F_{11}$ generation:}

Table 5 shows the correlation values at the $F_{11}$ generation. The correlation values between fresh fruit yield and days to flowering, number of flowers per truss and number of fruits per truss were negative and significant. Negative association was also observed between fruit yield and number of fruits per plant. Fresh fruit yield had positive association only with number of flowers per plant and number of trusses per plant in the $\mathrm{F}_{11}$ generation.

\section{$F_{12}$ generation:}

Table 6 shows the result of $F_{12}$ generation. It was observed that fruit yield correlated positively with all the characters and showed highly significant association with number of fruits per plant, number of trusses per plant and number of branches per plant. The yield contributing traits showed positive relationship with one another and also with days to flowering. 
Table.6: Correlation coefficients among different characters in $\mathbf{F}_{12}$ generation of tomato genotypes.

\begin{tabular}{|c|c|c|c|c|c|c|c|c|}
\hline 12 & $\mathrm{D} / \mathrm{FL}$ & $\mathrm{Fl} / \mathrm{P}$ & $\mathrm{Fr} / \mathrm{P}$ & $\mathrm{Tr} / \mathrm{P}$ & $\mathrm{Br} / \mathrm{P}$ & $\mathrm{FL} / \mathrm{T}$ & $\mathrm{Fr} / \mathrm{T}$ & Frfrtwt \\
\hline $\mathrm{D} / \mathrm{FL}$ & 1 & & & & & & & \\
\hline $\mathrm{Fl} / \mathrm{P}$ & .024 & 1 & & & & & & \\
\hline $\mathrm{Fr} / \mathrm{P}$ & .030 & $.971^{\text {** }}$ & 1 & & & & & \\
\hline $\mathrm{Tr} / \mathrm{P}$ & .056 & $.863^{* *}$ & $.855^{* *}$ & 1 & & & & \\
\hline $\mathrm{Br} / \mathrm{P}$ & $.154^{* *}$ & $.522^{* * *}$ & $.516^{* *}$ & $.524^{* *}$ & 1 & & & \\
\hline $\mathrm{FL} / \mathrm{T}$ & .065 & $.761^{* *}$ & $.720^{* *}$ & $.678^{* *}$ & $.469^{* * *}$ & 1 & & \\
\hline $\mathrm{Fr} / \mathrm{T}$ & .071 & $.807^{* * *}$ & $.780^{* * *}$ & $.732^{* *}$ & $.477^{* * *}$ & $.932^{* *}$ & 1 & \\
\hline Frfrtwt & $.111^{*}$ & .032 & $.124^{* * *}$ & $.152^{* *}$ & $.255^{\text {** }}$ & .008 & .031 & 1 \\
\hline
\end{tabular}

$\mathrm{D} / \mathrm{fl}=$ days to flowering,Fl/p=number of flowers/plant, $\mathrm{Fr} / \mathrm{p}=$ number of fruits/plant, $\mathrm{Tr} / \mathrm{p}=$ number of trusses/plant, $\mathrm{Br} / \mathrm{p}=$ number of branches/plant, $\mathrm{Fl} / \mathrm{t}=$ number of flowers/truss and $\mathrm{Fr} / \mathrm{t}=$ number of fruits/truss, FrFrwt=Fruit weight

\section{$\mathrm{F}_{7}$ GENERATION}

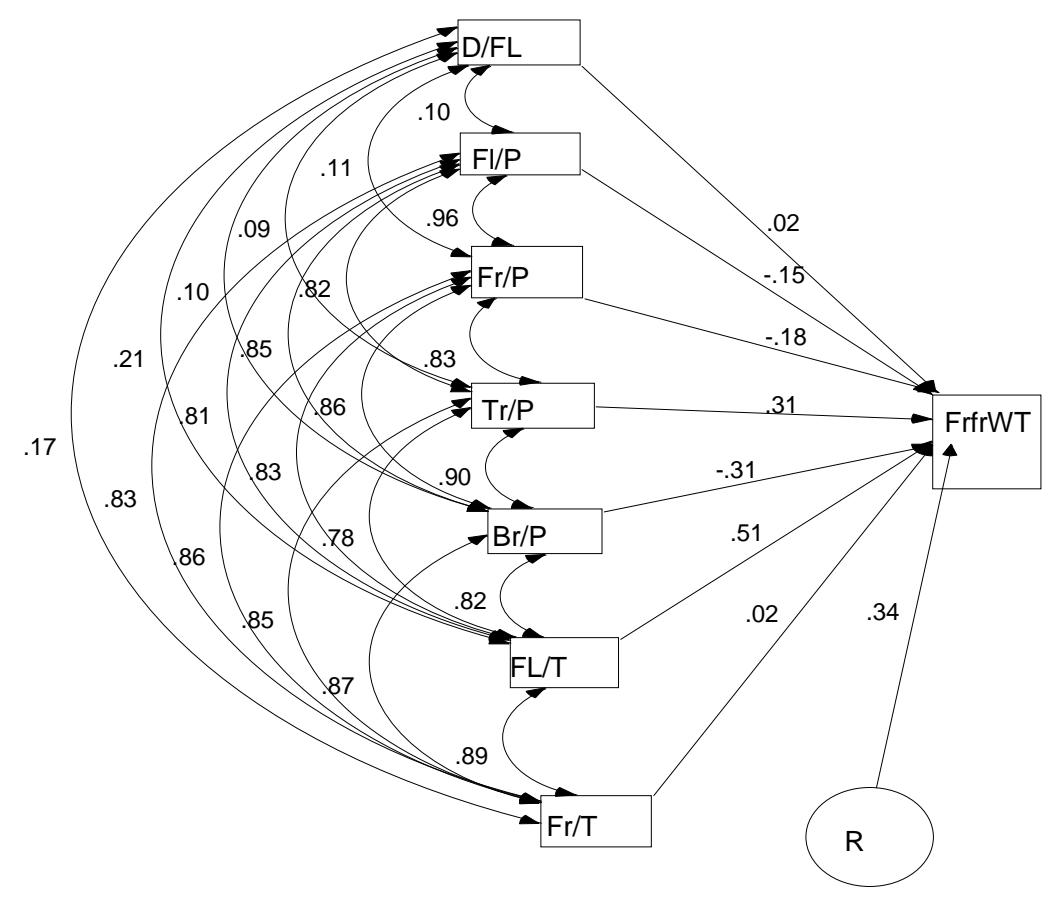

Fig.1: Path coefficient analysis of $\mathrm{F}_{7}$ generation.

$\mathrm{D} / \mathrm{fl}=$ days to flowering, $\mathrm{Fl} / \mathrm{p}=$ number of flowers/plant, $\mathrm{Fr} / \mathrm{p}=$ number of fruits/plant, $\mathrm{Tr} / \mathrm{p}=$ number of trusses/plant, $\mathrm{Br} / \mathrm{p}=$ number $\mathrm{of}$ branches/plant, $\mathrm{Fl} / \mathrm{t}=$ number of flowers/truss and $\mathrm{Fr} / \mathrm{t}=$ number of fruits/truss, FrFrwt=Fruit weight.

Table.7: Path coefficient analysis of $F_{7}$ generation showing direct and indirect effect seven components on tomato yield.

\begin{tabular}{|c|c|c|c|c|c|c|c|c|c|c|}
\hline Traits & $\begin{array}{l}\text { Direct } \\
\text { effect }\end{array}$ & $\mathrm{D} / \mathrm{FL}$ & FL/P & $\mathrm{FR} / \mathrm{P}$ & TR/P & $\mathrm{BR} / \mathrm{P}$ & $\mathrm{FL} / \mathrm{T}$ & $\mathrm{FR} / \mathrm{T}$ & $\begin{array}{l}\text { Total } \\
\text { Indirect }\end{array}$ & Corr/co \\
\hline $\mathrm{D} / \mathrm{FL}$ & 0.02 & & -0.015 & -0.02 & 0.028 & -0.031 & 0.107 & 0.003 & 0.072 & 0.092 \\
\hline $\mathrm{FL} / \mathrm{P}$ & -0.15 & 0.002 & & -0.173 & 0.254 & -0.264 & 0.413 & 0.017 & 0.259 & 0.109 \\
\hline $\mathrm{FR} / \mathrm{P}$ & -0.18 & 0.002 & -0.144 & & 0.257 & -0.266 & 0.423 & 0.017 & 0.289 & 0.109 \\
\hline $\mathrm{TR} / \mathrm{P}$ & 0.31 & 0.002 & -0.123 & -0.149 & & -0.279 & 0.398 & 0.017 & -0.139 & 0.171 \\
\hline $\mathrm{BR} / \mathrm{P}$ & -0.31 & 0.002 & -0.128 & -0.155 & 0.279 & & 0.418 & 0.017 & 0.433 & 0.123 \\
\hline FL/TR & 0.51 & 0.004 & -0.122 & -0.149 & 0.242 & -0.254 & & 0.018 & -0.261 & 0.249 \\
\hline FR/TR & 0.02 & 0.003 & -0.125 & -0.155 & 0.264 & -0.27 & 0.454 & & 0.171 & 0.191 \\
\hline Residual & & & & & & & & & & .34 \\
\hline
\end{tabular}

D/f1= days to flowering, F1/p= number of flowers/plant, Fr/p=number of fruits/plant, Tr/p=number of trusses/plant, Br/p=number of branches/plant, F1/t=number of flowers/truss and Fr/t=number of fruits/truss 
Fig. 2: Path coefficient analysis of $F_{8}$ generation •

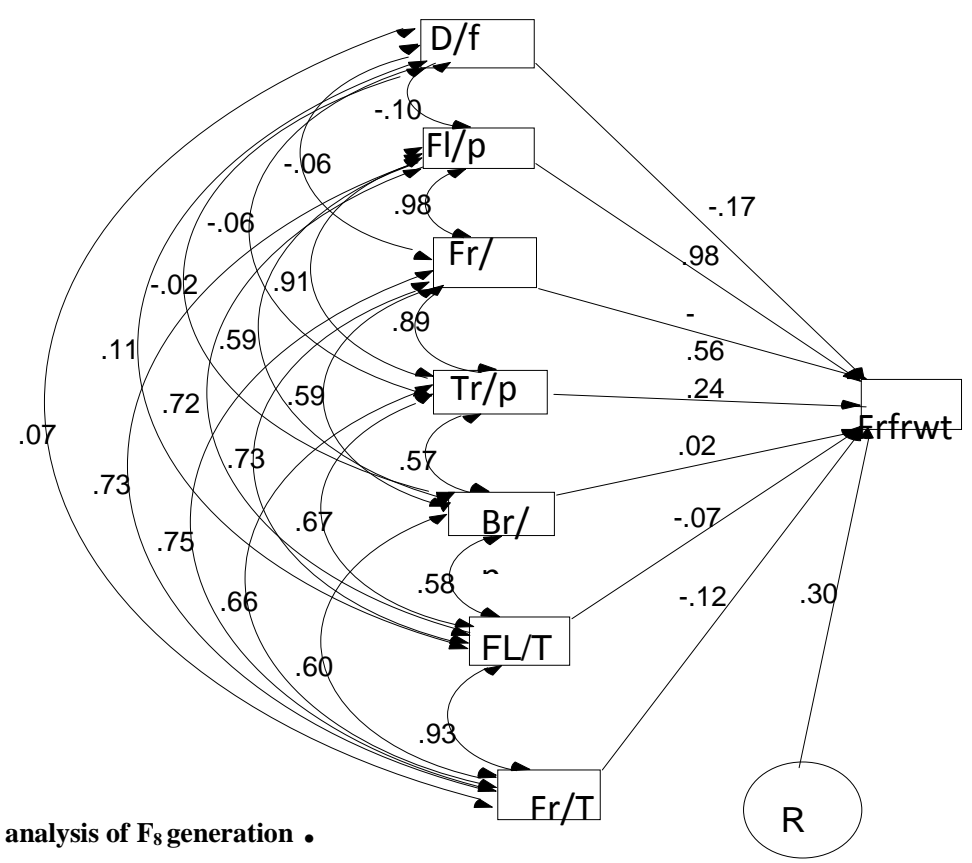

$\mathrm{D} / \mathrm{fl}=$ days to flowering,Fl/p=number of flowers/plant, $\mathrm{Fr} / \mathrm{p}=$ number of fruits $/ \mathrm{plant}, \mathrm{Tr} / \mathrm{p}=$ number of trusses $/ \mathrm{plant}, \mathrm{Br} / \mathrm{p}=\mathrm{number}$ of branches/plant, Fl/t=number of flowers/truss and Fr/t=number of fruits/truss, FrFrwt=Fruit weight

Table. 8; Path coefficient analysis of $F_{8}$ generation showing direct and indirect effect seven components on tomato yield.

\begin{tabular}{|c|c|c|c|c|c|c|c|c|c|c|}
\hline Traits & $\begin{array}{l}\text { Direct } \\
\text { effects }\end{array}$ & $\mathrm{D} / \mathrm{FL}$ & $\mathrm{FL} / \mathrm{P}$ & $\mathrm{FR} / \mathrm{P}$ & $\mathrm{TR} / \mathrm{P}$ & $\mathrm{BR} / \mathrm{P}$ & $\mathrm{FL} / \mathrm{T}$ & $\mathrm{FR} / \mathrm{T}$ & $\begin{array}{l}\text { Total Indirect } \\
\text { effects }\end{array}$ & $\begin{array}{l}\text { Corr; } \\
\text { coef }\end{array}$ \\
\hline $\mathrm{D} / \mathrm{FL}$ & -.17 & & -.098 & .034 & -.014 & .0004 & -.008 & -.008 & -.0936 & -.263 \\
\hline $\mathrm{FL} / \mathrm{P}$ & .98 & -.017 & & -.549 & .218 & .012 & -.050 & -.088 & -.4696 & .510 \\
\hline $\mathrm{FR} / \mathrm{P}$ & -.56 & .010 & .960 & & .214 & .012 & -.051 & -.09 & 1.055 & .495 \\
\hline $\mathrm{TR} / \mathrm{P}$ & .24 & .010 & .892 & -.498 & & .011 & -.0469 & -.079 & .289 & .529 \\
\hline $\mathrm{BR} / \mathrm{P}$ & .02 & .003 & .578 & -.330 & .137 & & -.0406 & -.072 & .2756 & .295 \\
\hline FL/TR & -.07 & -.0187 & .7056 & -.4088 & .1608 & .0116 & & -.1116 & -.079 & .268 \\
\hline FR/TR & -.12 & -.0119 & .7154 & -.42 & .1584 & .012 & -.065 & & .3885 & .268 \\
\hline Residual & & & & & & & & & & .30 \\
\hline
\end{tabular}

$\mathrm{D} / \mathrm{fl}=$ days to flowering, $\mathrm{Fl} / \mathrm{p}=$ number of flowers/plant, $\mathrm{Fr} / \mathrm{p}=$ number of fruits $/ \mathrm{plant}, \mathrm{Tr} / \mathrm{p}=$ number of trusses $/ \mathrm{plant}, \mathrm{Br} / \mathrm{p}=$ number of branches/plant, $\mathrm{Fl} / \mathrm{t}=$ number of flowers/truss and $\mathrm{Fr} / \mathrm{t}=$ number of fruits/truss

\section{Path Coefficient Analysis}

Path diagrams showing cause and effect relationships of fresh fruit yield and its components are represented in figures 1-6. The direct and indirect effects of the various yield components in each generation are presented in Tables 7 to 12 .

\section{F $_{7}$ generation:}

The results of the path analysis of the $\mathrm{F}_{7}$ generation are as shown in Table 7 . The path analysis revealed that number of flowers per truss exerted the maximum direct effect $(0.51)$ followed by number of trusses per plant (o.31), days to flowering (0.02) and number of fruits per truss (0.02). Negative direct effects were observed with number of flowers per plant $(-0.15)$, number of fruits per plant $(-0.18)$ and number of branches per plant $(-0.31)$. High and positive indirect effects were obtained with all the traits via flowers per truss. Number of fruits per truss had the highest indirect effect $(0.454)$ followed by fruits per plant $(0.423)$ and branches per plant (0.418) via flowers per truss. 


\section{F8 generation:}

The result of the path coefficient analysis of the $\mathrm{F}_{8}$ generation are presented in Table 8 . Negative direct effect on yield was observed with days to flowering $(-0.17)$. Its indirect effect through number of flowers per plant was also negative. Number of flowers per Plant had the highest positive direct effect (0.98). The number of fruits . (-0.56) and high positive indirect effect . (0.960) via number of flowers per plant. Number of trusses per plant showed moderate positive direct effect and high positive indirect influence via number of flowers per plant. Number of branches exerted low positive direct effect and made high positive indirect contribution through number of flowers per plant. Number of flowers per truss and number of fruits per truss exerted negative indirect effect via number of flowers per plant, their indirect contributions through number of flowers per plant were high and positive. The correlations of trusses per plant, branches per plant, flowers per truss and fruits per truss were positive and significant with fresh fruit yield

\section{F generation:}

Path analysis of $F_{9}$ revealed that number of flowers per plant exerted the maximum direct effect of 0.97 followed by number of fruits per truss $(0.16)$, trusses per plant (0.05), fruits per plant (0.02) and days to flowering (0.02). Number of branches per plant and number of flowers per truss exerted negative direct influence, their indirect contributions were high and positive.

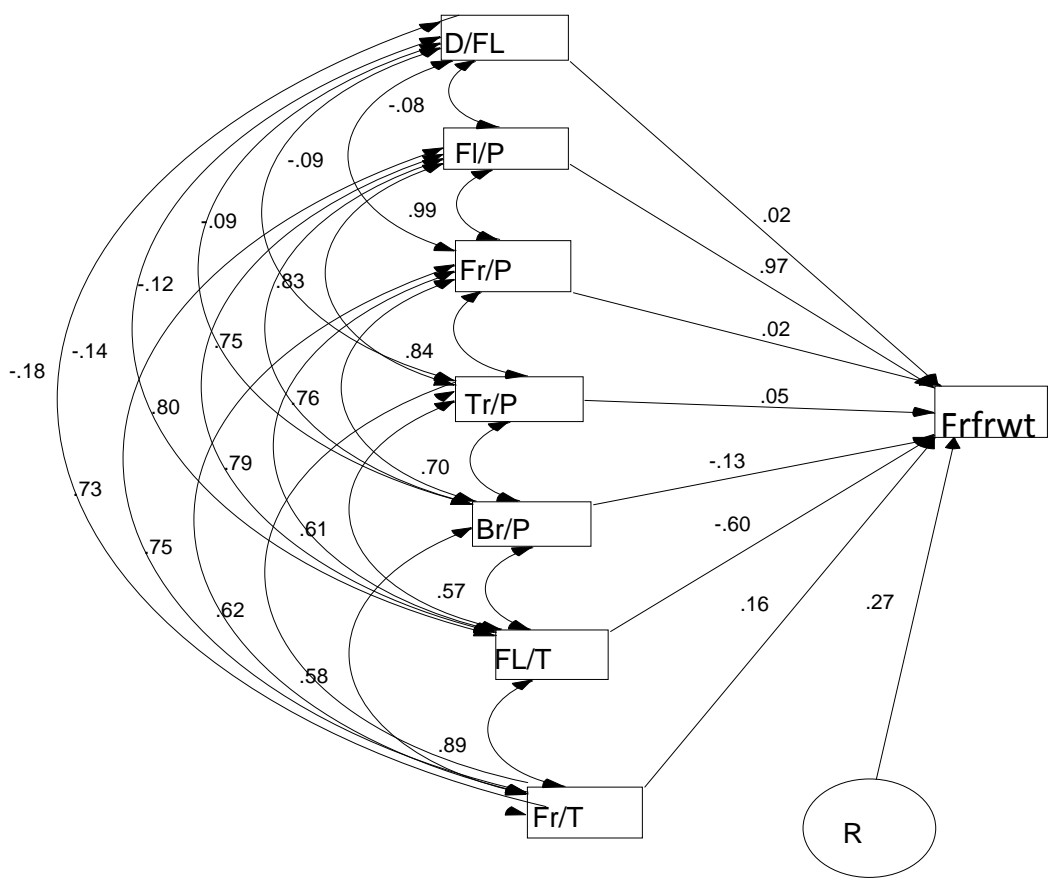

Fig. 3: Path coefficient analysis of $F_{9}$ generation.

$\mathrm{D} / \mathrm{fl}=$ days to flowering,Fl/p=number of flowers/plant, $\mathrm{Fr} / \mathrm{p}=$ number of fruits/plant,

$\mathrm{Tr} / \mathrm{p}=$ number of trusses/plant, $\mathrm{Br} / \mathrm{p}=$ number of branches/plant, $\mathrm{Fl} / \mathrm{t}=$ number of flowers/truss and Fr/t=number of fruits/truss FrFrwt=Fruit weight.

Table.9; Path coefficient analysis of generation 9 showing direct and indirect effect seven components on tomato yield.

\begin{tabular}{|c|c|c|c|c|c|c|c|c|c|c|c|}
\hline Traits & $\begin{array}{l}\text { Direct } \\
\text { effect }\end{array}$ & $\mathrm{D} / \mathrm{FL}$ & $\mathrm{FL} / \mathrm{P}$ & $\mathrm{FR} / \mathrm{P}$ & $\mathrm{TR} / \mathrm{P}$ & $\mathrm{BR} / \mathrm{P}$ & $\mathrm{FL} / \mathrm{T}$ & $\mathrm{FR} / \mathrm{T}$ & $\begin{array}{l}\text { Total } \\
\text { effects }\end{array}$ & Indirect & Corr/ \\
\hline $\mathrm{D} / \mathrm{FL}$ & .02 & & -.0776 & -.0018 & -.0045 & .0156 & .084 & -.0288 & -.00131 & & .0069 \\
\hline $\mathrm{FL} / \mathrm{P}$ & .97 & -.0016 & & .0198 & .0415 & -.0975 & -.48 & .1168 & -.401 & & .569 \\
\hline FR/P & .02 & -.0018 & .9603 & & .042 & -.0988 & -.474 & .12 & .05477 & & .5677 \\
\hline TR/P & .05 & -.0018 & .8051 & .0168 & & -.091 & -.366 & .0992 & .4623 & & .5123 \\
\hline $\mathrm{BR} / \mathrm{P}$ & -.13 & -.0024 & .7275 & .0152 & .035 & & -.342 & .0928 & .5261 & & .3961 \\
\hline FL/TR & -.60 & -.0028 & .776 & .0158 & .0305 & -.0741 & & .142 .4 & .8878 & & .2878 \\
\hline FR/TR & .16 & -.0036 & .7081 & .015 & .031 & -.0754 & -.534 & & .1411 & & .3011 \\
\hline Residual & & & & & & & & & & & .27 \\
\hline
\end{tabular}

$\mathrm{D} / \mathrm{fl}=$ days to flowering,Fl/p=number of flowers/plant,

$\mathrm{Fr} / \mathrm{p}=$ number of fruits/plant, $\mathrm{Tr} / \mathrm{p}=$ number of trusses/plant,

$\mathrm{Br} / \mathrm{p}=$ number of branches/plant, $\mathrm{Fl} / \mathrm{t}=$ number of flowers/truss and

$\mathrm{Fr} / \mathrm{t}=$ number of fruits/truss 


\section{$F_{10}$ generation:}

The results of the path analysis of the $\mathrm{F}_{10}$ generation are as presented in Table 10. The results revealed that number of trusses per plant showed the highest positive direct effect (0.63) followed by number of fruits per plant with moderate positive direct effect (0.13) and high positive indirect effect via number of trusses per plant. The direct contribution of number of flowers per plant on fresh fruit yield was negative ( -0.45$)$. Number of branches exerted low direct effect (0.02) with high positive indirect contribution via number of trusses per plant. Number of flowers per truss and number of fruits per truss showed negative influence on yield at this generation but high positive indirect effect through number of trusses per plant.

\section{Fi1 generation:}

The result of path analysis of $F_{11}$ generation (Table 11) revealed high and positive direct effect of number of flowers ( 0.95) and number of trusses ( 0.30 ) on fresh fruit yield. Negative direct influence (0.09 ) was observed with days to flowering. Its indirect effect through number of flowers per plant was negative and very low (-0.0009). Number of fruits per plant showed high negative direct influence
(-0.59) and high positive indirect effect (0.912) via number of flowers per plant on fresh fruit yield. Number of trusses per plant showed moderate positive direct effect $(0.30)$ and high positive indirect effect (0.684) via number of flowers per plant. Number of branches per plant, number of flowers per truss and number of fruits per truss showed negative direct effect and positive indirect influence through number of flowers per plant.

\section{$F_{12}$ generation:}

The path analysis of the $F_{12}$ is presented in Table 12 . A very high positive direct influence (1.39) was observed with number of fruits per plant. Number of flowers per plant exerted high negative direct effect on fruit yield at this generation. Its indirect effect through number of fruits per plant was high and positive. Number of trusses per plant exhibited moderate positive direct effect $(0.26)$ and high positive indirect effect (1.195) via number of fruits per plant. Number of branches showed positive direct effect (0.28) on fruit yield. Its indirect effect via fruits per plant was positive and high (0.7228). Number of flowers per truss exerted negative direct contribution (-0.08) and positive indirect effect (1.0008) through fruits per plant.

\section{$\mathrm{F}_{10}$ GENERATION}

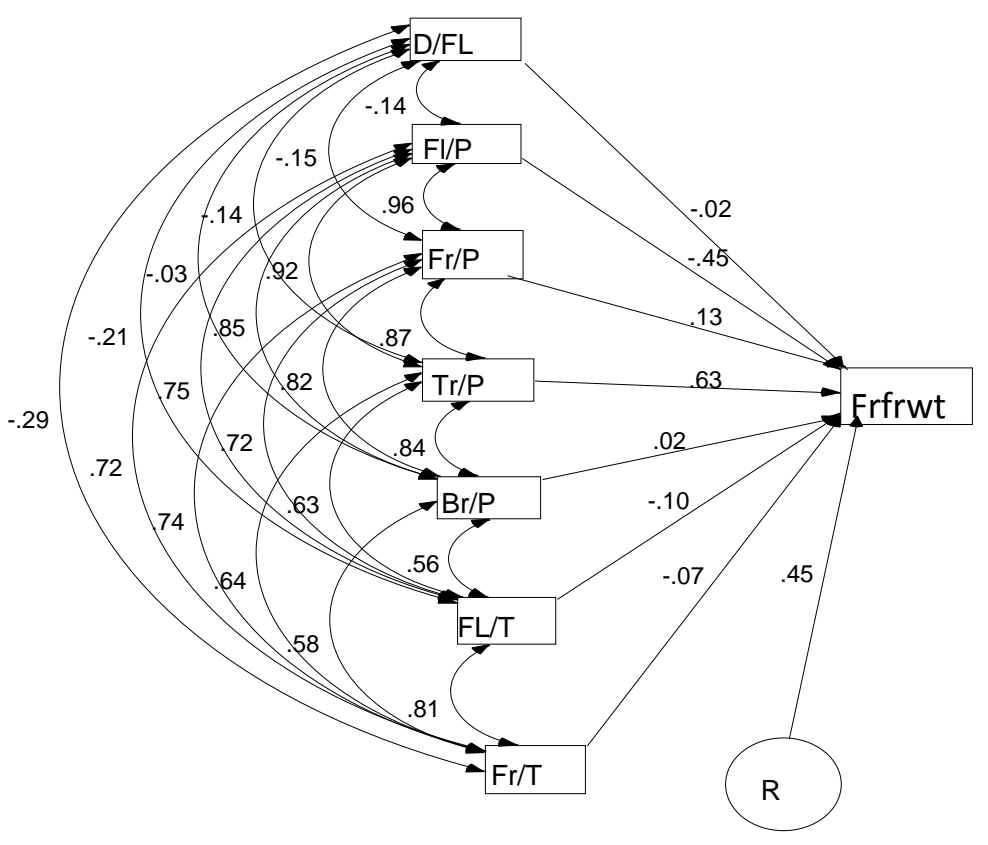

Fig 4: Path coefficient analysis of $F_{10}$ generation

$\mathrm{D} / \mathrm{fl}=$ days to flowering, $\mathrm{Fl} / \mathrm{p}=$ number of flowers/plant, $\mathrm{Fr} / \mathrm{p}=$ number of fruits $/ \mathrm{plant}, \mathrm{Tr} / \mathrm{p}=$ number of trusses $/ \mathrm{plant}, \mathrm{Br} / \mathrm{p}=$ number of branches/plant, Fl/t=number of flowers/truss and Fr/t=number of fruits/truss, FrFrwt=Fruit weight. 
Table. 10; Path coefficient Analysis of $F_{10}$ generation showing direct and indirect effect seven

\begin{tabular}{|c|c|c|c|c|c|c|c|c|c|c|}
\hline Traits & Direct effects & $\mathrm{D} / \mathrm{FL}$ & FL/P & FR/P & TR/P & $\mathrm{BR} / \mathrm{P}$ & FL/T & $\mathrm{FR} / \mathrm{T}$ & $\begin{array}{l}\text { Total } \\
\text { Indirect } \\
\text { effects }\end{array}$ & Corr/Coef \\
\hline $\mathrm{D} / \mathrm{FL}$ & -.02 & & .063 & -.0195 & -.0882 & -.0006 & .021 & .0203 & $\begin{array}{l}-.004 \\
-.04\end{array}$ & $\begin{array}{l}.024 \\
\end{array}$ \\
\hline FL/P & -.45 & .0028 & & .1248 & .5796 & .017 & -.075 & -.0504 & .5988 & . 1488 \\
\hline FR/P & .13 & .003 & -.432 & & .5481 & .0164 & -.072 & -.0518 & .0117 & .1417 \\
\hline TR/P & .63 & .0028 & -.414 & .1131 & & .0168 & -.063 & -.0448 & -.3891 & .2409 \\
\hline $\mathrm{BR} / \mathrm{P}$ & .02 & .0006 & -.3825 & .1066 & .5292 & & -.056 & -.0406 & .1573 & .1773 \\
\hline FL/TR & -.10 & .0042 & -.3325 & .0936 & .3969 & .0112 & & -.0567 & .1117 & .0117 \\
\hline FR/TR & -.07 & .0058 & -.324 & .0962 & .4032 & .0116 & -.081 & & .1118 & .0418 \\
\hline Residual & & & & & & & & & & .45 \\
\hline
\end{tabular}

$\mathrm{D} / \mathrm{fl}=$ days to flowering,Fl/p=number of flowers/plant, Fr/p=number of fruits/plant, Tr/p=number of trusses/plant,

$\mathrm{Br} / \mathrm{p}=$ number of branches/plant, $\mathrm{Fl} / \mathrm{t}=$ number of flowers/truss and $\mathrm{Fr} / \mathrm{t}=$ number of fruits/truss

$\mathrm{F}_{11}$ GENERATION

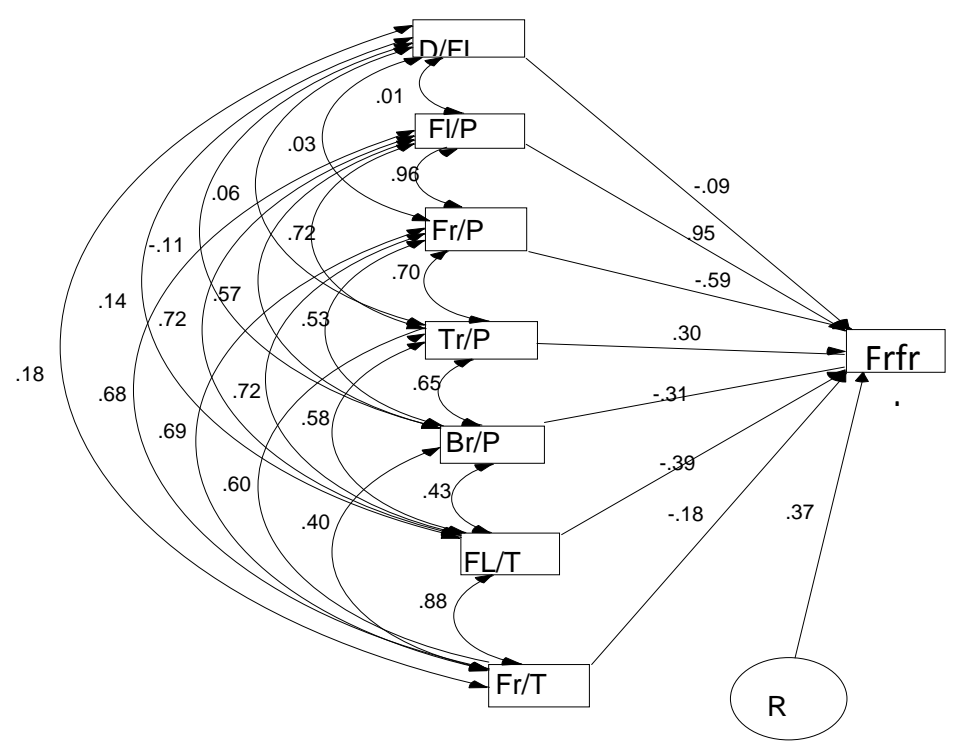

Fig. 5: Path coefficient analysis of $F_{11}$ generation

.D/fl=days to flowering,Fl/p=number of flowers/plant, $\mathrm{Fr} / \mathrm{p}=$ number of fruits/plant, $\mathrm{Tr} / \mathrm{p}=$ number of trusses/plant, Br/p=number of branches/plant, $\mathrm{Fl} / \mathrm{t}=$ number of flowers/truss and $\mathrm{Fr} / \mathrm{t}=$ number of fruits/truss, FrFrwt=Fruit weight.

Table.11: Path coefficient analysis of $F_{11}$ generation showing direct and indirect effect seven components on tomato yield.

\begin{tabular}{|c|c|c|c|c|c|c|c|c|c|c|c|c|}
\hline Traits & $\begin{array}{l}\text { Direct } \\
\text { effect }\end{array}$ & $\mathrm{D} / \mathrm{FL}$ & FL/P & FR/P & TR/P & $\mathrm{BR} / \mathrm{P}$ & \multicolumn{2}{|c|}{$\mathrm{FL} / \mathrm{T}$} & $\mathrm{FR} / \mathrm{T}$ & $\begin{array}{l}\text { Total } \\
\text { effects }\end{array}$ & Indirect & Corr/Coef \\
\hline $\mathrm{D} / \mathrm{FL}$ & -.09 & $\begin{array}{l}.0095 \\
-\end{array}$ & -.0177 & $\begin{array}{l}.018 \\
-\end{array}$ & .0341 & -.0546 & \multicolumn{2}{|c|}{-.0324} & -.0431 & -.1331 & & .0095 \\
\hline FL/P & $\begin{array}{l}.95 \\
-\end{array}$ & $\begin{array}{l}.0009 \\
-\end{array}$ & & .5664 & .216 & -.1767 & -.2808 & -.1224 & -.9312 & & .0188 & \\
\hline $\mathrm{FR} / \mathrm{P}$ & .59 & $\begin{array}{l}.0027 \\
-\end{array}$ & .912 & & .21 & -.1643 & -.2808 & -.1242 & .55 & & -.04 & \\
\hline $\mathrm{TR} / \mathrm{P}$ & $\begin{array}{l}.30 \\
-\end{array}$ & $\begin{array}{l}.0054 \\
-\end{array}$ & .684 & $\begin{array}{l}-.413 \\
-\end{array}$ & & -.2015 & -.2262 & -.108 & -.2701 & & .0299 & \\
\hline $\mathrm{BR} / \mathrm{P}$ & $\begin{array}{l}.31 \\
-\end{array}$ & $\begin{array}{l}0099 \\
-\end{array}$ & .5415 & $\begin{array}{l}.3127 \\
-\end{array}$ & .195 & & -.1677 & -.072 & .1742 & & -.1358 & \\
\hline FL/TR & $\begin{array}{l}.39 \\
-\end{array}$ & $\begin{array}{l}.0126 \\
-\end{array}$ & .684 & $\begin{array}{l}.4248 \\
-\end{array}$ & .174 & -.1333 & & -.1584 & .1289 & & -.2611 & \\
\hline $\begin{array}{l}\text { FR/TR } \\
\text { Residual }\end{array}$ & .18 & .0162 & .646 & .4071 & .18 & -.124 & -.3432 & & -.0645 & & $\begin{array}{l}-.2445 \\
.37 \\
\end{array}$ & \\
\hline
\end{tabular}
D/

$\mathrm{fl}=$ days to flowering, $\mathrm{Fl} / \mathrm{p}=$ number of flowers/plant, $\mathrm{Fr} / \mathrm{p}=$ number of fruits/plant, $\mathrm{Tr} / \mathrm{p}=$ number of trusses $/ \mathrm{plant}, \mathrm{Br} / \mathrm{p}=\mathrm{number}$ of branches/plant, $\mathrm{Fl} / \mathrm{t}=$ number of flowers/truss and $\mathrm{Fr} / \mathrm{t}=$ number of fruits/truss 
Atugwu A. I. and Uguru M.I.

\section{$\mathrm{F}_{12}$ Generation}

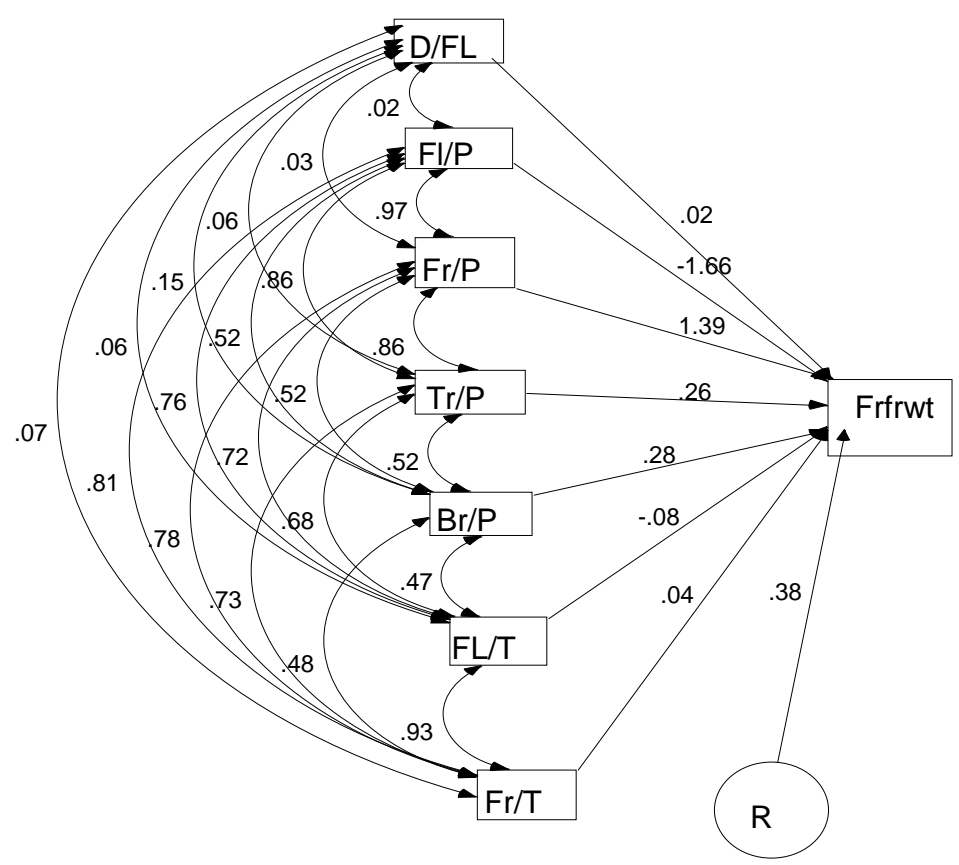

Fig.6: Path coefficient analysis of $F_{12}$ generation

$\mathrm{D} / \mathrm{fl}=$ days to flowering, $\mathrm{Fl} / \mathrm{p}=$ number of flowers/plant, $\mathrm{Fr} / \mathrm{p}=$ number of fruits/plant, $\mathrm{Tr} / \mathrm{p}=$ number of trusses/plant, Br/p=number of branches/plant, $\mathrm{Fl} / \mathrm{t}=$ number of flowers/truss and $\mathrm{Fr} / \mathrm{t}=$ number of fruits/truss, FrFrwt=Fruit weight.

Table.12: Path coefficient analysis of $F_{12}$ generation showing direct and indirect effect seven components on tomato yield.

\begin{tabular}{|c|c|c|c|c|c|c|c|c|c|c|}
\hline Traits & $\begin{array}{l}\text { Direct } \\
\text { effect }\end{array}$ & $\mathrm{D} / \mathrm{FL}$ & $\mathrm{FL} / \mathrm{P}$ & $\mathrm{FR} / \mathrm{P}$ & $\mathrm{TR} / \mathrm{P}$ & $\mathrm{BR} / \mathrm{P}$ & $\mathrm{FL} / \mathrm{T}$ & $\mathrm{FR} / \mathrm{T}$ & $\begin{array}{l}\text { Total Indirect } \\
\text { effects }\end{array}$ & Corr/Col/CO \\
\hline $\mathrm{D} / \mathrm{FL}$ & .02 & & -.00332 & .0417 & .0156 & .042 & -.0048 & .0028 & .09398 & .11398 \\
\hline $\mathrm{FL} / \mathrm{P}$ & -1.66 & .0004 & & 1.3483 & .2236 & .1456 & -.0608 & .0324 & 1.6895 & .0295 \\
\hline $\mathrm{FR} / \mathrm{P}$ & 1.39 & .0006 & -1.6102 & & .2236 & .1456 & -.0576 & .0312 & -1.2668 & .1232 \\
\hline TR/P & .26 & .0012 & -1.4276 & 1.1954 & & .1456 & -.0544 & .0372 & -.1026 & .1574 \\
\hline $\mathrm{BR} / \mathrm{P}$ & .28 & .003 & -.8632 & .7228 & .1352 & & -.0376 & .0192 & -.0206 & .2594 \\
\hline FL/TR & -.08 & .0012 & -1.2616 & 1.0008 & .1768 & .1316 & & .0372 & .086 & .006 \\
\hline FR/TR & .04 & .0014 & -.1 .3446 & 1.0842 & .1898 & .1344 & -.0744 & & -.0092 & .0308 \\
\hline Residual & & & & & & & & & & .38 \\
\hline
\end{tabular}

$\mathrm{D} / \mathrm{fl}=$ days to flowering, $\mathrm{Fl} / \mathrm{p}=$ number of flowers/plant,

$\mathrm{Fr} / \mathrm{p}=$ number of fruits/plant, $\mathrm{Tr} / \mathrm{p}=$ number of trusses/plant,

$\mathrm{Br} / \mathrm{p}=$ number of branches/plant, $\mathrm{Fl} / \mathrm{t}=$ number of flowers/truss and

$\mathrm{Fr} / \mathrm{t}=$ number of fruits/truss 


\section{DISCUSSION}

\section{Correlation Studies:}

The positive and highly significant correlations between fresh fruit yield and all but one of the yield components in five generations is an indication that fresh fruit yield in tomato depends largely on the contributions of the yield traits. This is in line with previous findings ( Moya et al., 1996; Singh et al., 1997; Das et al., 1998; Gosh et al., 2010). Significant correlations observed among the yield components other than their association with the fresh fruit yield suggest that an increase in any of the traits will result in the increase of the other. However, the very low positive and negative correlations observed between fruit yield and days to flowering in all the generations suggest that delay in flowering is associated with a decline in fruit yield. By the same reasoning earliness in flowering would favour fresh fruit yield in tomato. Muhammad et al. (2006) had similar results on soya bean. This suggests that late flowering genotypes would produce fewer flowers, fruits and trusses per plant. The negative correlation observed at $\mathrm{F}_{11}$ generation with fresh fruit yield and some of the yield components could be attributed to selection efficiency at the $F_{10}$ generation or environmental influence. Falconer (1967) reported that the strength and direction of correlation in different character combination depend on the nature of experimental material and the environmental condition under which they are studied. Positive and significant correlation observed with fresh fruit yield and number of fruits per plant at the $F_{8}, F_{9}$, $\mathrm{F}_{10}$ and $\mathrm{F}_{12}$ generations is in tandem with earlier reports (Kurma, et al., 1979; Aruna, 1992; Jawaharlal, 1994). In all the characters studied the strongest and highest positive correlations were observed between fruit yield and number of flowers per plant, number of trusses per plant and number of branches per plant. Therefore, for the improvement of fresh fruit yield in tomato, breeders should place emphases on the genotypes with high number of flowers, trusses and branches.

Path Coefficient Analysis: Path coefficient analysis measures the direct influence and contribution of one trait to the other. It enables the plant breeder to measure the direct and indirect effects of the various traits, thereby providing the basis for earmarking the traits of economic importance. The path analysis revealed that number of flowers per plant, number of flower per truss, number of trusses per plant and number of fruits per plant are the four important yield traits for fresh fruit yield improvement in tomato. They exerted high positive direct effects on fruit yield in the different generations. The consistent high positive direct effect of number of flowers per plant in three $\left(F_{8}, F_{9}\right.$ and $\left.F_{11}\right)$ out of the six generations studied suggest that it is a good contributor to fresh fruit yield in tomato. The negative direct effect exerted by number of flowers on fruit yield at the $\mathrm{F}_{7}, \mathrm{~F}_{10}$ and $\mathrm{F}_{12}$ could be attributed to its high positive indirect effect via number of flowers per truss, number of trusses per plant and number of fruits per plant. The positive direct and indirect effects exerted by number of flowers per plant provides explanation for its high positive correlations with the fresh fruit yield in all the generations. The highest and positive direct effect (0.51) observed with number of flowers per truss at $\mathrm{F}_{7}$ generation was nullified by its negative indirect effect through number of flowers per plant $(-0.122)$, number of fruits per plant $(-0.149)$ and number of branches per plant $(-0.254)$. Therefore, the positive correlation observed between number of flowers per truss and fruit yield was due to its indirect effect via number of trusses per plant(0.242). The highest and positive direct effect (1.39) observed with number of fruits per plant at $F_{12}$ generation was nullified by its indirect effect via number of flowers per plant (-1.6102) and number of flowers per truss (-0.0576). The positive correlation observed with the fruit yield could be attributed to its positive indirect effect through number of trusses per plant (0.224), number of branches per plant $(0.146)$ and number of fruits per truss (0.0312). Truss per plant recorded positive direct and positive indirect effects on yield in all the generations thereby validating the high positive correlation with fruit yield in the six generations. This study therefore revealed that number of flowers which had the highest direct effect on yield in three out of the six generations studied should be considered as the best contributing trait to fresh fruit yield. It is very evident that selection based on this trait will favour fruit yield in tomato. The residual effects of 0.34 at $\mathrm{F}_{7}, 0.30$ at $\mathrm{F}_{8}, 0.27$ at $\mathrm{F}_{9}, 0.45$ at $\mathrm{F}_{10}$, 0.37 at $F_{11}$ and 0.38 at $F_{12}$ observed determined how best the independent factors accounted for the variability of the dependent factor. The recorded values would appear to suggest that fresh fruit yield in tomato is well accounted for by the seven traits studied that the proportion of variations due to environment was minimal.

\section{ACKNOWLEDGEMENT}

We thank the Agricultural Research Council of Nigeria for the funds released under the Competitive Agricultural Research Grant Scheme (CARGS) to support part of this research.

\section{REFERENCES}

Akbar, M., M. Tariqub. M. Anwar. M. Ali. and N. Igbal. (2003). Variability correlation and path coefficient Studies in summer mustard (Brassica juncea L.). Asian J. of Plant Sci. 2(9):696-698.

Ali, N., F. Javaidfar and A. A. Attary. (2002). Genetic variability, correlation and path coefficient of yield and its components in winte rapeseed (Brassica napus L.). Pak. J. Bot., 35(2):145- 150.) 
Ali, N., J. Farzad. Y. E. Jaferieh and M. Y. Mirza. (2003). Relationship among yield components and Selection criteria for yield improvement in winter rapeseed (Brassica napus L.). Pak. J. Bot. 35(2):167-174.

Aruna, S. (1992).Studies on the performance of certain $\mathrm{F}_{1}$ hybrids in tomato ( Lycopersicon esculentum Mill.).M.Sc. Thesis. Tamil Nadu Agricultural University, Coimbatore.

Das, B., M. H. Hazarika and P. K.Das. (1998). Genetic variability and correlation in fruit characters of tomato (Lycopersicon esculentum Mill.) Ann. Agric. Res. 19(1): 77-80.

Davis, J. N and G. E. Hobson. (1981). The constituents of tomato fruit-the influence of environment, nutrition and genotype. CRC Crit. Rev. Food Sci. Nutr., 15:569-582.

Dewey, D. R and K. H. Lu. (1959). A correlation and path co-efficient analysis of components of crested wheat grass seed production. Agron. J. 51(9):515-518.

Falconer, D.S. (1967). Introduction of quantitative genetics. Oliver and Boyd, Ltd., Tweeddale Court, Bdinburgh 1.39a Welback Street, London, W.I.

Gosh, K.P., A.K.M. Islam and M. M. Hossain. (2010). Variability and Character association in $\mathrm{F}_{2}$ Segregating population of Different Commercial Hybrid of Tomato Solanum lycopersicum L. J. Appl. Sci. Environ. Manag. 14 (2) 91-95.

Grierson, D and A. A. Kader. (1986). Fruit ripening and quality. In: The Tomato Crop: Atherton JG Rudick J (Eds.). A Scientific Basis for Improvement. pp:243-275.

Graffius, J. E., (1959) Heterosis in barley Agron J., 5: $551-554$

Hidayatullah, S.A., Jatol, A. Ghafoor and T. Mahamood . (2008). Path Coefficient analysis of yield component in tomato (Lycopersicon esculentum Mill). Pak. J. Bot. 40(2) 627- 635.

Jawaharlal, M. (1994). Genetic studies for fruit yield and quality characteristics in tomato (Lycopersicon esculentum Mill.).Ph.D. Thesis. Tamil Nadu Agricultural University,Coimbatore.
Kalloo, G. (1988). Vegetable breeding, Volume 1.C.R.C. Press. Inc. Noca Raton, Florida, pp: 105-128.

Kang, M. S., O. Sosa and J. D. Miller (1989). Path analysis for percent fiber, cane and sugar yield in sugarcane. Crop Sci.29:1481-1483.

Kurmar, N.,C. R. Muthukrishnan and I. Irulappan. (1979).Correlation studies and path analysis in segregating generation of tomato (Lycopersicon esculentum Mill.) South India Horticulture, 27(1\&2):4

Mahmudul, H. A. Babar. M. S. Tariq. A H. Muhammad, S. Syed and S. Sarwaralam. (2005). Correlation and Path Coefficient studies in Induced Mutants of Chickpea (Cicer aritinum L.) Pall J. Bot, 37(2): 293-298.

Muhammad, A. A. Maazar and A Ghafoor (2006). Character correlation ad Path Coefficient in Soybean Ghycine Max (L) Merrill. Pak J. Bot, 38(1): 121-130

Rani C.I D. veeraragavathatham and S. Sanjutha (2008) studies on Correlation ad path Coefficient analysis on yield attributes in Root knot Nematode resistant $\mathrm{F}_{1}$ hybrids Tomato Journal of Applied Sciences Research, 4(3): 287-295.

Sarawgi, A.K., N.K. Rastogi and Dk Soni DK (1997).Correlaton and path analysis in rice accessions from Madhya Pradesh. Field Crops Research, 52:161-167.

Shalini, S., R. A. Sheriff., R.S., Kulkarni and P.Venkantarmans (2000). Correlation and path analysis of Indian mustard germplasm. Indian Crop Res. 1(2):139-143.

Singh, D.N., A. Sahu and A.K. Parida. (1997). Genetic variability and Correlation studies in tomato (Lycopersicon esculentum Mill). Environ. and Eco. 15(1): 117-121. 